\title{
Nutritional composition of herbage of different Jerusalem artichoke genotypes
}

\author{
H. Pinar ${ }^{1}$, K. Kara ${ }^{2}$, F. Hanci ${ }^{1}$ and M. Kaplan ${ }^{3,4}$ \\ University of Erciyes \\ ${ }^{1}$ Faculty of Agriculture, Department of Horticulture, \\ ${ }^{2}$ Faculty of Veterinary Medicine, Department of Animal Nutrition and Nutritional Diseases, 38280, Kayseri, Turkey \\ ${ }^{3}$ Faculty of Agriculture, Department of Field Crops, 38039 Kayseri, Turkey
}

KEY WORDS: chemical composition, energy, gas production, herbage, Jerusalem artichoke, minerals

Received: 30 January 2021

Revised: 25 March 2021

Accepted: 23 April 2021

\begin{abstract}
This study was conducted to investigate chemical composition, mineral contents and in vitro gas-methane productions of post-harvest herbage of different Jerusalem artichoke genotypes. In total, 16 different Jerusalem artichoke genotypes were used in the present experiments. Plants were harvested during the tuber harvests. Present findings revealed that Jerusalem artichoke herbage could offer a good source of fibre and minerals for ruminants. Crude protein contents varied between $5.82-13.36 \%$, ether extract between $0.65-2.42 \%$, condensed tannins between $0.95-1.67 \%$, acid detergent fibre (ADF) between 31.67-45.71\%, neutral detergent fibre (NDF) between $38.77-53.27 \%$ and crude ash between $9.89-16.85 \%$. Total gas and methane productions respectively varied between $26.06-46.12 \mathrm{ml}$ and $3.81-8.96 \mathrm{ml}$, metabolizable energy (ME) between 5.82-8.52 MJ/kg dry matter (DM), organic matter digestibility (OMD) between $43.30-60.20 \%$ and net energy for lactation $\left(\mathrm{NE}_{L}\right)$ between 2.65-4.93 MJ/kg DM. Macro- and microelements contents of the majority of the Jerusalem artichoke genotypes were greater than legumes and Gramineae forage species. It was concluded that Jerusalem artichoke herbage had a rich nutritional composition and could offer a good source of roughage for ruminants especially in dry and lactation periods.
\end{abstract}

${ }^{4}$ Corresponding author:

e-mail: mahmutkaplan5@hotmail.com various parts of the world (Gunnarsson et al., 2014). It is commonly used in human nutrition and animal feeding (Losavio et al., 1996). This vegetable was adapted to different climate and soil conditions and is able to grow at different $\mathrm{pH}$ ranges (4.5-8.2) and in saline soils. Resistance to pests and diseases, no need for excessive fertilization and high yields have made Jerusalem artichoke a significant species in low-input agriculture (Slimestad et al., 2010; Yang et al., 2010). Plant leaves and stems (above ground sections) were used in feeding domestic animals in the previous century (Becker and Nehring, 1969). The potential use of this plant, which for a long time has been forgotten in ruminant feeding, has recently 
been re-explored (Razmkhah et al., 2017). Plant height, tuber colour, number of branches, stems and leaves vary with the plant genetics, soil types and climate conditions (Szpunar-Krok et al., 2016).

Jerusalem artichoke herbage has about 6-9\% crude protein (CP) content at harvest, it is insufficient in $\mathrm{P}$ and rich in $\mathrm{Ca}, \mathrm{Mg}$ and $\mathrm{K}$ (Seiler, 1988). It was reported that Jerusalem artichoke herbage with high/ medium nutritional composition, metabolic energy content and satisfactory digestion parameters may constitute a reliable roughage source for ruminants (Ersahince and Kara, 2017). The nutritional composition of Jerusalem artichoke tubers and herbage vary significantly with the cultivars (Seiler and Campbell, 2004). Nutritional composition, metabolic energy and digestibility of Jerusalem artichoke silage or herbage should be investigated for the potential use of this plant in ruminant diets (Karsli and Bingol, 2009).

The in vitro gas production technique is a rapid, easy and cost-effective method, thus commonly used to determine potential nutritive value, chemical composition and mineral content of feeds (Kaplan et al., 2014). Anaerobic fermentation of forage and highfibre feed generates methane that contributes to global warming and waste of feed energy. Recent researches thus have focused on methane emission levels of the forages (Lin et al., 2013; Kara et al., 2018). Different outcomes were reported about methanogenic effects and anti-methanogenic compound contents of different roughage sources (Kara et al., 2016; 2018).

The studies on Jerusalem artichoke herbage mostly focused on in vitro digestion, methanogenic effects, nutrient contents, ruminant digestibility and rumen fermentation at different plant growth stages (Ersahince and Kara, 2017) and quality traits of Jerusalem artichoke silages (Karsli and Bingol, 2009). However, there are not comprehensive studies about the nutritional composition of different Jerusalem artichoke genotypes. Therefore, this study was conducted to investigate the chemical composition, mineral contents, gas-methane production, net energy for lactation, metabolic energy and organic matter digestibility of post-harvest green herbage of different Jerusalem artichoke genotypes and to compare the genotypes in terms of these traits.

\section{Material and methods}

\section{Plant material}

Sixteen different Jerusalem artichoke accessions collected from nine provinces of Turkey constituted the plant material of this study (Table 1). All genotypes were found to be different morphologically as presented by Hanci and Tuncer (2019).
Table 1. Sample number and geographical origin of Jerusalem artichoke accessions

\begin{tabular}{llllll}
\hline Sample Collection area & $\begin{array}{l}\text { Tuber } \\
\text { colour }\end{array}$ & Sample & Collection area & $\begin{array}{l}\text { Tuber } \\
\text { colour }\end{array}$ \\
\hline $38-1$ & Kayseri/Incesu & yellow & $33-1$ & Mersin & yellow \\
$40-2$ & Kırsehir & yellow & $40-1$ & Kırşehir & yellow \\
$06-1$ & Ankara/Beypazarı red & $40-3$ & Kış̧ehir & yellow \\
$07-1$ & Antalya/Alanya & yellow & $50-1$ & Nevşehir/Gülşehir & yellow \\
$19-1$ & Çorum/Sungurlu & red & $50-3$ & Nevşehir/Avanos & yellow \\
$19-2$ & Çorum/Sungurlu yellow & $50-4$ & Nevşehir/Ürgüp & yellow \\
$19-3$ & Çorum/Ferizli & yellow & $58-1$ & Sivas/Gemerek & red \\
$19-4$ & Çorum & red & $66-2$ & Yozgat/Boğazlıyan & red \\
\hline
\end{tabular}

Accessions were collected in November 2018. Tubers of each accession were stored in a refrigerator until March 2019. Then, three tubers of each accession were planted in a 10-litre pot and grown until November 2019.

\section{Chemical analysis}

Sampling was performed during the tuber harvest. Jerusalem artichoke fresh herbage was dried at $70{ }^{\circ} \mathrm{C}$ for $48 \mathrm{~h}$ and ground to pass a 1-mm sieve. The crude ash content of the samples was determined through ashing samples at $550{ }^{\circ} \mathrm{C}$ for $8 \mathrm{~h}$. Ether extract content was determined with the use of a Soxhlet device (VELP Solvent Extractors SER 148/6; VELP Scientific, Bohemia, NY, USA). Nitrogen (N) content was measured by the Kjeldahl method. The crude protein content of samples was calculated as $\mathrm{N} \times 6.25$ (AOAC International, 2005). Cell wall components: acid detergent fibre (ADF) and neutral detergent fibre (NDF) content were determined with the use of an ANKOM 200 Fiber Analyzer (ANKOM Technology Corp., Fairport, NY, USA) in accordance with the method specified by Van Soest et al. (1991). Condensed tannin content was determined with the use of butanol-HCl method (Makkar et al., 1995).

\section{Mineral analyses}

About $0.5 \mathrm{~g}$ of dry samples were taken from the plants to determine minerals content. Ten $\mathrm{ml}$ of nitric acid + perchloric acid mixture was added to samples and subjected to wet digestion until obtaining 1-ml samples. Following the digestion procedure, resultant solutions were diluted with distilled water and readings were performed in an inductively coupled plasma spectrophotometer (ICP-OES) (Optima 4300 DV; Perkin-Elmer, Shelton, CT, USA) to determine $\mathrm{P}, \mathrm{K}, \mathrm{Ca}, \mathrm{Mg}, \mathrm{Na}, \mathrm{Fe}, \mathrm{Mn}, \mathrm{Zn}, \mathrm{Cu}$ and $\mathrm{B}$ contents in the samples (AOAC International, 2005).

\section{In vitro Hohenheim gas production technique}

Rumen fluid was obtained from two beef cattle (Simmental breed, at 16 months of age and about 
$670 \mathrm{~kg}$ body weight) fed diet containing roughage feed (approximately 20\% of total mix feed on a dry matter (DM) basis) and concentrate feed (approximately $80 \%$ of total mix feed on a DM basis). Rumen fluid was collected $4 \mathrm{~h}$ after morning feeding. Rumen fluid was collected into a thermos pre-filled with water at $39{ }^{\circ} \mathrm{C}$ under $\mathrm{CO}_{2}$ gas, and filtered with 4 layers of cheesecloth in the laboratory. The technique was carried out according to the procedures of Menke and Steingass (1988). The plant samples were incubated in rumen fluid and buffer mixture in 100-ml glass syringes (Model Fortuna, Wertheim, Germany). One litre of buffer mixture included $474 \mathrm{ml}$ of bi-distilled water, $237.33 \mathrm{ml}$ of macro-mineral solution $(5.7 \mathrm{~g}$ of $\mathrm{Na}_{2} \mathrm{HPO}_{4}, 6.2 \mathrm{~g}$ of $\mathrm{KH}_{2} \mathrm{PO}_{4}$ and $0.6 \mathrm{~g}$ of $\mathrm{MgSO}_{4}$ in 11 of bi-distilled water), $237.33 \mathrm{ml}$ of buffer solution ( $35 \mathrm{~g}$ of $\mathrm{NaHCO}_{3}$ and $4 \mathrm{~g}$ of $\mathrm{NH}_{4} \mathrm{HCO}_{3}$ in 11 of bidistilled water), $0.12 \mathrm{ml}$ of trace-mineral solution (13.2 $\mathrm{g}$ of $\mathrm{CaCl}_{2} \cdot 2 \mathrm{H}_{2} \mathrm{O}, 10 \mathrm{~g}$ of $\mathrm{MnCI}_{2} \cdot 4 \mathrm{H}_{2} \mathrm{O}, 1 \mathrm{~g}$ of $\mathrm{CoCI}_{2} \cdot 6 \mathrm{H}_{2} \mathrm{O}$ and $0.8 \mathrm{~g}$ of $\mathrm{FeCI}_{3} \cdot 6 \mathrm{H}_{2} \mathrm{O}$ in $100 \mathrm{ml}$ of bi-distilled water), $1.22 \mathrm{ml}$ of resazurine solution $(0.1 \mathrm{~g}$ of resazurine in $100 \mathrm{ml}$ of bi-distilled water) and $50 \mathrm{ml}$ of reducing solution $\left(285 \mathrm{mg}\right.$ of $\mathrm{Na}_{2} \mathrm{~S} \cdot 7 \mathrm{H}_{2} \mathrm{O}$ and $4 \mathrm{ml}$ of $1 \mathrm{~N} \mathrm{NaOH}$ in $96 \mathrm{ml}$ of bi-distilled water) (Kara et al., 2016). Dried plant samples $(200 \pm 10 \mathrm{mg})$ were weighed in triplicates in glass syringes. The $30 \mathrm{ml}$ of the rumen fluid and buffer mixture at a 1:2 $(\mathrm{v} / \mathrm{v})$ ratio were added to each syringe. In addition, three blank syringes (blank syringes; rumen fluid + buffer mixture) were used to calculate the total gas production. After closing the clips on the silicon tube, the syringes were gently shaken, and the clips were opened to remove gas by pushing the piston upwards to achieve complete gas removal. The clip was closed, the initial volume recorded, and the syringes were incubated in a water bath at $39^{\circ} \mathrm{C}$ for up to $24 \mathrm{~h}$.

\section{Determination of total gas and methane production}

Within incubation, the total gas volume was recorded from the calibrated scale on the syringe for $24 \mathrm{~h}$. After measuring the total gas volume at $24 \mathrm{~h}$, the tubing of the plastic syringe outlet was inserted into the inlet of the methane analyzer (Sensor, Europe GmbH, Erkrath, Germany) and the piston was pushed to insert the accumulated gas into the analyzer. The methane as a percentage (\%) of the total gas was displayed on a personal computer. This value was used for the calculation of methane in the total gas volume (Kara et al., 2015).

\section{Metabolic energy and organic matter digestibility}

The metabolizable energy (ME) and organic matter digestibility (OMD) of the samples were calculated with the use of the following equations (Menke and Steingass, 1988):

$$
\begin{gathered}
\mathrm{ME}(\mathrm{MJ} / \mathrm{kg} \mathrm{DM})=2.20+0.136 \times \mathrm{GP}+0.0057 \times \\
\mathrm{CP}+0.00029 \times \mathrm{EE}^{2} \\
\mathrm{OMD}(\% \mathrm{DM})=14.88+0.889 \times \mathrm{GP}+0.45 \times \\
\mathrm{CP}+0.0651 \times \mathrm{ash} .
\end{gathered}
$$

The net energy for lactation $\left(\mathrm{NE}_{\mathrm{L}}\right)$ was calculated according to the method of Blümmel and Ørskov (1993):

$$
\begin{gathered}
\mathrm{NE}_{\mathrm{L}}(\mathrm{MJ} / \mathrm{kg} \mathrm{DM})=0.115 \times \mathrm{GP}+0.0054 \times \mathrm{CP}+ \\
0.014 \times \mathrm{EE}-0.0054 \times \mathrm{ash}-0.36
\end{gathered}
$$

where: $\mathrm{GP}-24 \mathrm{~h}$ net gas production $(\mathrm{ml} / 200 \mathrm{mg}$ $\mathrm{DM}), \mathrm{CP}$ - crude protein (\% DM), ash - ash content $(\% \mathrm{DM})$ and $\mathrm{EE}-$ ether extract (\%DM).

\section{Data analysis}

Experimental data were subjected to analysis of variance in accordance with the randomized plots design with the use of SAS software (SAS 9.0; SAS Institute Inc., Cary, NC, USA). Significant means were compared with the use of LSD test $(P \leq 0.01)$.

\section{Results}

\begin{tabular}{|c|c|c|c|c|c|c|}
\hline \multirow{2}{*}{ Indices } & EE & CT & ADF & NDF & $\mathrm{CP}$ & $\mathrm{CA}$ \\
\hline & \multicolumn{6}{|l|}{$\% / D M$} \\
\hline \multicolumn{7}{|c|}{ Genotypes } \\
\hline 06-1 & $1.37^{\text {fgh }}$ & $1.67^{a}$ & $39.30^{\text {de }}$ & $48.77^{\text {de }}$ & $7.12^{g h}$ & $14.70^{\text {cd }}$ \\
\hline $07-1$ & $1.38^{\mathrm{fg}}$ & $0.96^{i}$ & $34.88^{g h}$ & $43.00^{h}$ & $5.82^{j}$ & $11.95^{f}$ \\
\hline $19-1$ & $1.72^{\mathrm{d}}$ & $1.22^{\mathrm{de}}$ & $38.75^{\mathrm{ef}}$ & $48.35^{\mathrm{ef}}$ & $11.63^{b}$ & $15.13^{b c}$ \\
\hline $19-2$ & $1.98^{c}$ & $1.13^{\mathrm{efg}}$ & $41.70^{b}$ & $50.84^{\text {bcd }}$ & $9.45^{\mathrm{d}}$ & $15.35^{b c}$ \\
\hline $19-3$ & $2.11^{b}$ & $1.54^{b}$ & $39.52^{\text {cde }}$ & $48.33^{\text {ef }}$ & $13.36^{a}$ & $16.85^{\mathrm{a}}$ \\
\hline $19-4$ & $1.30^{g h i}$ & $0.96^{i}$ & $36.83^{\mathrm{fg}}$ & $44.65^{\text {gh }}$ & $8.69^{e}$ & $12.76^{\text {ef }}$ \\
\hline $33-1$ & $1.18^{i}$ & $1.24^{\mathrm{d}}$ & $33.70^{\mathrm{h}}$ & $43.77^{\mathrm{h}}$ & $7.69^{f g}$ & $13.22^{\mathrm{e}}$ \\
\hline $38-1$ & $0.88^{j}$ & $1.06^{\mathrm{gh}}$ & $36.06^{9}$ & $43.80^{h}$ & $10.26^{c}$ & $9.89^{9}$ \\
\hline $40-1$ & $1.47^{\mathrm{ef}}$ & $1.12^{\mathrm{fg}}$ & $45.08^{a}$ & $52.87^{a b}$ & $8.78^{e}$ & $14.35^{\mathrm{cd}}$ \\
\hline $50-1$ & $1.42^{f}$ & $1.07^{\mathrm{gh}}$ & $41.36^{b c}$ & $50.84^{\mathrm{bcd}}$ & $6.76^{\mathrm{hi}}$ & $15.02^{b c}$ \\
\hline $50-3$ & $1.57^{\mathrm{e}}$ & $1.00^{\mathrm{hi}}$ & $45.71^{a}$ & $53.27^{a}$ & $6.68^{\mathrm{hi}}$ & $15.03^{b c}$ \\
\hline $50-4$ & $2.12^{b}$ & $1.15^{\text {defg }}$ & $40.94^{\mathrm{bcd}}$ & $49.57^{\text {cde }}$ & $8.64^{e}$ & $15.93^{\mathrm{ab}}$ \\
\hline $58-1$ & $2.42^{\mathrm{a}}$ & $0.95^{\mathrm{i}}$ & $41.68^{b}$ & $50.22^{\text {cde }}$ & $7.83^{f}$ & $16.06^{\mathrm{ab}}$ \\
\hline $66-2$ & $0.65^{k}$ & $1.18^{\mathrm{def}}$ & $40.78^{b c d}$ & $51.38^{a b c}$ & $6.67^{\mathrm{hi}}$ & $14.46^{\mathrm{cd}}$ \\
\hline $40-2$ & $1.86^{c}$ & $1.37^{c}$ & $38.55^{\text {ef }}$ & $46.14^{\mathrm{fg}}$ & $9.51^{\mathrm{d}}$ & $15.31^{b c}$ \\
\hline 40-3 & $1.26^{\mathrm{hi}}$ & $1.52^{\mathrm{b}}$ & $31.67^{i}$ & $38.77^{i}$ & $6.47^{i}$ & $13.67^{\text {de }}$ \\
\hline$P$-value & $* *$ & $* *$ & $* *$ & $* *$ & $* *$ & $* *$ \\
\hline LSD & 0.12 & 0.10 & 1.98 & 2.24 & 0.63 & 1.13 \\
\hline
\end{tabular}

There were highly significant differences among genotypes in nutrients contents $(P \leq 0.01)$ (Table 2$)$. Ether extract of the genotypes varied between $0.65-2.42 \%$, condensed tannin between $0.95-$

Table 2. Chemical composition of Jerusalem artichoke genotypes

EE - ether extract; CT - condensed tannin; ADF - acid detergent fibre; NDF - neutral detergent fibre; CP - crude protein; CA - crude ash; DM - dry matter; ${ }^{a-i}$ - means with different superscripts withhin the same columne are significantly different at $P \leq 0.05$; ${ }^{* *}-P \leq 0.01$; LSD - least significant difference 
1.67\%, ADF between $31.67-45.71 \%$, NDF between $38.77-53.27 \%$, crude protein (CP) between $5.82-13.36 \%$ and crude ash between $9.89-16.85 \%$. The greatest CP contents were obtained for 19-1, 19-3 and 38-1 genotypes.

There were significant differences in gas-methane productions, $\mathrm{ME}, \mathrm{OMD}$ and $\mathrm{NE}_{\mathrm{L}}$ values among the examined genotypes $(P<0.01)$. The lowest values of these parameters were obtained for 38-1 genotype and the greatest values were obtained for 33-1 genotype. Gas production varied between 26.06$46.12 \mathrm{ml}$, methane production between $3.81-8.96 \mathrm{ml}$, ME values between 5.82-8.52 MJ/kg DM, OMD values between $43.30-60.20 \%$ and $\mathrm{NE}_{\mathrm{L}}$ values between 2.65-4.93 MJ/kg DM (Table 3).
33-1 genotype and it did not differ statistically from 50-4 genotype. The greatest $\mathrm{Ca}$ content was obtained for 33-1 genotype, Na content for 38-1 genotype and $\mathrm{P}$ content for 40-3 genotype.

The greatest $\mathrm{B}$ (98.3 ppm DM) and $\mathrm{Fe}$ (2741.4 ppm DM) contents were obtained for 50-1 genotype, and the lowest B content (35.9 ppm DM) was obtained for 38-1 genotype whereas the lowest Fe content was obtained for 50-3 (279.9 ppm DM) and 58-1 (291.1 ppm DM) genotypes. Cu contents varied between 103-122 ppm DM with the lowest value for 58-1 genotype; howerver 07-1, 19-2, 381, 40-1, 50-3, 40-2 and 40-3 genotypes were also placed in the same statistical group. The greatest value of $\mathrm{Cu}$ was stated for 19-4 genotype, but 06-

Table 3. Gas and methane productions ( $\mathrm{GP}$ and $\mathrm{CH}_{4}$, respectively), metabolizable energy (ME), organic matter digestibility (OMD) and net energy for lactation $\left(\mathrm{NE}_{\mathrm{L}}\right)$ of Jerusalem artichoke genotypes

\begin{tabular}{|c|c|c|c|c|c|c|}
\hline Indices & $\begin{array}{l}\mathrm{GP}, \\
\mathrm{ml}\end{array}$ & $\begin{array}{l}\mathrm{CH}_{4}, \\
\mathrm{ml}\end{array}$ & $\begin{array}{l}\mathrm{CH}_{4}, \\
\%\end{array}$ & $\begin{array}{l}\text { ME, } \\
\text { MJ/kg DM }\end{array}$ & $\begin{array}{l}\text { OMD, } \\
\%\end{array}$ & $\begin{array}{l}\mathrm{NE}_{\mathrm{L}} \\
\mathrm{MJ} / \mathrm{kg} \mathrm{DM}\end{array}$ \\
\hline \multicolumn{7}{|c|}{ Genotypes } \\
\hline 06-1 & $43.04^{b}$ & $6.19 \mathrm{~cd}$ & $14.38^{d}$ & $8.09^{b}$ & $57.30^{\mathrm{bc}}$ & $4.57^{b}$ \\
\hline $07-1$ & $31.96^{\mathrm{e}}$ & $5.10^{e}$ & $15.98^{b c}$ & $6.58^{\mathrm{e}}$ & $46.69^{h}$ & $3.30^{\mathrm{e}}$ \\
\hline $19-1$ & $27.93^{f}$ & $4.47^{f}$ & $15.99^{b c}$ & $6.07^{f}$ & $45.93^{h}$ & $2.86^{f}$ \\
\hline $19-2$ & $35.17^{d}$ & $5.72^{d}$ & $16.27^{\mathrm{bc}}$ & $7.03^{d}$ & $50.88^{g}$ & $3.68^{d}$ \\
\hline $19-3$ & $40.24^{c}$ & $6.59^{b c}$ & $16.50^{\mathrm{bc}}$ & $7.75^{c}$ & $57.76^{b}$ & $4.28^{c}$ \\
\hline $19-4$ & $40.45^{c}$ & $6.83^{b}$ & $16.88^{b c}$ & $7.76^{c}$ & $56.09^{c d}$ & $4.29^{c}$ \\
\hline $33-1$ & $46.12^{a}$ & $8.96^{a}$ & $19.42^{\mathrm{a}}$ & $8.52^{a}$ & $60.20^{a}$ & $4.93^{a}$ \\
\hline $38-1$ & $26.06^{g}$ & $3.81^{\mathrm{g}}$ & $14.62^{\mathrm{d}}$ & $5.80^{g}$ & $43.30^{i}$ & $2.65^{g}$ \\
\hline $40-1$ & $27.27^{f}$ & $4.64^{\mathrm{ef}}$ & $16.99^{b c}$ & $5.96^{\mathrm{fg}}$ & $44.01^{i}$ & $2.77^{\mathrm{fg}}$ \\
\hline $50-1$ & $39.98^{c}$ & $6.83^{b}$ & $17.09^{b c}$ & $7.68^{c}$ & $54.44^{\mathrm{ef}}$ & $4.21^{\mathrm{c}}$ \\
\hline $50-3$ & $39.31^{c}$ & $6.45^{\mathrm{bc}}$ & $16.39^{b c}$ & $7.59^{c}$ & $53.81^{f}$ & $4.14^{c}$ \\
\hline $50-4$ & $39.57^{c}$ & $6.53^{b c}$ & $16.49^{b c}$ & $7.63^{c}$ & $54.98^{\text {def }}$ & $4.18^{c}$ \\
\hline $58-1$ & $40.43^{c}$ & $6.71^{b c}$ & $16.60^{b c}$ & $7.74^{c}$ & $55.39^{\text {de }}$ & $4.28^{c}$ \\
\hline $66-2$ & $28.39^{f}$ & $4.87^{\mathrm{ef}}$ & $17.14^{b}$ & $6.10^{f}$ & $44.06^{i}$ & $2.87^{f}$ \\
\hline $40-2$ & $35.36^{d}$ & $5.79^{d}$ & $16.35^{b c}$ & $7.06^{d}$ & $51.5^{g}$ & $3.70^{d}$ \\
\hline 40-3 & $40.20^{c}$ & $6.42^{\mathrm{bc}}$ & $15.95^{c}$ & $7.70^{c}$ & $54.42^{\mathrm{ef}}$ & $4.24^{c}$ \\
\hline$P$-value & $* *$ & $* *$ & $* *$ & ** & ** & $* *$ \\
\hline LSD & 1.52 & 0.56 & 1.16 & 0.21 & 1.48 & 0.17 \\
\hline
\end{tabular}

$\mathrm{DM}$ - dry matter; ${ }^{\text {a-i }}$ - means with different superscripts within each columne are significantly different at $P \leq 0.05 ;{ }^{* *}-P \leq 0.01$; LSD - least significant difference

There were quite significant differences in the macroelements contents among the examined genotypes. K contents varied between 2392-33053 ppm DM, Mg contents between 2693-6736 ppm DM, $\mathrm{Ca}$ contents between 16474-45233 ppm DM, Na contents between 269-583 ppm DM, P contents between 558-2933 ppm DM and S contents varied between 804-2313 ppm DM. The greatest $\mathrm{K}$ content was obtained for 06-1, 50-3 and 50-4 genotypes. The greatest Mg content was stated for 19-2 genotype and it was followed by 33-1, 06-1 and 50-1 genotypes. The greatest $\mathrm{S}$ content was obtained for
1, 19-3, 19-4, 33-1, 50-1, 50-4 and 66-2 genotypes were also placed in the same statistical group.

The lowest Mn content (57.9 ppm DM) was obtained for 50-4 genotype but it did not differ statistically from 19-2, 50-3 and 50-4 genotypes. The greatest Mn content (97.2 ppm DM) was obtained for 33-1 genotype, but 07-1, 19-4 and 38-1 genotypes were statistically in the same group. The lowest Zn content was obtained for 66-2 (31.3 ppm DM) and 38-1 (34.9 ppm DM) genotypes. The greatest $\mathrm{Zn}$ content was obtained from 50-1 (63.8 ppm DM) and 50-4 (63.1 ppm DM) genotypes (Table 4). 
Table 4. Mineral contents of Jerusalem artichoke genotypes

\begin{tabular}{|c|c|c|c|c|c|c|c|c|c|c|c|}
\hline \multirow{2}{*}{ Indices } & $\mathrm{K}$ & $\mathrm{Mg}$ & $\mathrm{Ca}$ & $\mathrm{Na}$ & $\mathrm{P}$ & $S$ & $\mathrm{~B}$ & $\mathrm{Cu}$ & $\mathrm{Fe}$ & $\mathrm{Mn}$ & $\mathrm{Zn}$ \\
\hline & \multicolumn{11}{|l|}{$\mathrm{ppm} / \mathrm{DM}$} \\
\hline \multicolumn{12}{|c|}{ Genotypes } \\
\hline 06-1 & $33053^{a}$ & $6478^{a}$ & $21568^{g}$ & $438^{d}$ & $1373^{d}$ & $1070^{g}$ & $72.9^{\mathrm{cd}}$ & $116.1^{\mathrm{ab}}$ & $484.8^{i}$ & $90.3^{b}$ & $55.6^{b}$ \\
\hline $07-1$ & $27568^{b}$ & $4554^{\mathrm{de}}$ & $28581^{d}$ & $313^{\mathrm{fg}}$ & $890^{\mathrm{fg}}$ & $1029 \mathrm{~g}$ & $75.6^{c}$ & $109.6^{\text {bcd }}$ & $486.7^{i}$ & $93.8^{\mathrm{ab}}$ & $48.1^{\text {cde }}$ \\
\hline $19-1$ & $30918^{a}$ & $5687^{b}$ & $25928^{\mathrm{ef}}$ & $269^{h}$ & $785^{\mathrm{g}}$ & $1774^{c}$ & $67.4^{\mathrm{ef}}$ & $112.6^{b c}$ & $1034.0^{e f}$ & $88.2^{b c}$ & $41.4^{\text {ghi }}$ \\
\hline $19-2$ & $25419^{c}$ & $6736^{a}$ & $24048^{f}$ & $436^{d}$ & $879^{f g}$ & $2044^{b}$ & $66.7^{\text {ef }}$ & $110.1^{\mathrm{bcd}}$ & $370.5^{\mathrm{j} k}$ & $63.8^{g}$ & $44.9^{\mathrm{efg}}$ \\
\hline $19-3$ & $24842^{c}$ & $2701^{g}$ & $16474^{i}$ & $285^{\text {gh }}$ & $1322^{d}$ & $1080^{g}$ & $51.1^{\mathrm{hi}}$ & $114.5^{\mathrm{abc}}$ & $2366.2^{b}$ & $72.7^{\text {ef }}$ & $38.5^{\mathrm{ij}}$ \\
\hline $19-4$ & $24781^{c d}$ & $5151^{c}$ & $37605^{b}$ & $422^{d}$ & $1046^{e}$ & $1266^{e}$ & $89.3^{b}$ & $122.0^{\mathrm{a}}$ & $1698.8^{d}$ & $93.4^{\mathrm{ab}}$ & $49.1^{\mathrm{cd}}$ \\
\hline $33-1$ & $22768^{\text {def }}$ & $6498^{a}$ & $45233^{a}$ & $508^{c}$ & $1113^{e}$ & $2313^{a}$ & $68.9^{\mathrm{de}}$ & $114.3^{a b c}$ & $1075.3^{e}$ & $97.2^{\mathrm{a}}$ & $44.0^{\mathrm{fgh}}$ \\
\hline $38-1$ & $24291^{c-f}$ & $3414^{f}$ & $20112^{g h}$ & $583^{a}$ & $1353^{d}$ & $1506^{d}$ & $35.9^{k}$ & $107.1^{\mathrm{cd}}$ & $595.8^{h}$ & $91.5^{\mathrm{ab}}$ & $34.9^{\mathrm{jk}}$ \\
\hline $40-1$ & $22570^{\mathrm{ef}}$ & $5641^{b}$ & $23810^{f}$ & $324^{f}$ & $896^{\mathrm{fg}}$ & $1006^{g}$ & $63.9^{f}$ & $103.5^{d}$ & $568.6^{\mathrm{hi}}$ & $78.3^{\text {de }}$ & $46.9^{\text {def }}$ \\
\hline $50-1$ & $24669^{\text {cde }}$ & $6407^{a}$ & $27955^{\text {de }}$ & $501^{c}$ & $1332^{d}$ & $1119^{f g}$ & $98.3^{a}$ & $114.8^{\mathrm{abc}}$ & $2741.4^{\mathrm{a}}$ & $81.7^{d}$ & $63.8^{\mathrm{a}}$ \\
\hline $50-3$ & $31814^{a}$ & $4891^{\mathrm{cd}}$ & $18647^{\mathrm{hi}}$ & $312^{\mathrm{fg}}$ & $829^{f g}$ & $1318^{e}$ & $55.3^{g h}$ & $108.1^{\mathrm{bcd}}$ & $279.9^{\prime}$ & $58.8^{g}$ & $40.5^{\mathrm{hi}}$ \\
\hline $50-4$ & $31549^{a}$ & $4884^{c d}$ & $32364^{c}$ & $388^{e}$ & $2222^{b}$ & $2202^{a}$ & $57.2^{\mathrm{g}}$ & $114.8^{\mathrm{abc}}$ & $383.2^{j}$ & $57.9^{9}$ & $63.1^{\mathrm{a}}$ \\
\hline $58-1$ & $22344^{\mathrm{fg}}$ & $5607^{b}$ & $29066^{d}$ & $286^{\text {gh }}$ & $558^{h}$ & $804^{h}$ & $75.8^{c}$ & $103.0^{d}$ & $291.1^{\mathrm{kl}}$ & $83.3^{b c}$ & $44.5^{\mathrm{efg}}$ \\
\hline $66-2$ & $23581^{c-f}$ & $2693^{f}$ & $16699^{i}$ & $408^{d e}$ & $1793^{c}$ & $1219^{e f}$ & $45.1^{j}$ & $116.4^{\mathrm{abc}}$ & $2150.5^{c}$ & $74.6^{\mathrm{ef}}$ & $31.3^{\mathrm{k}}$ \\
\hline $40-2$ & $20392^{g}$ & $5027^{c}$ & $33858^{c}$ & $382^{e}$ & $903^{f}$ & $1019^{g}$ & $46.2^{j}$ & $107.9^{b c d}$ & $946.5^{\mathrm{fg}}$ & $73.6^{\text {ef }}$ & $59.1^{b}$ \\
\hline 40-3 & $24302^{c-f}$ & $4452^{e}$ & $20353^{g h}$ & $545^{b}$ & $2933^{a}$ & $1082^{g}$ & $49.9^{i j}$ & $107.5^{\mathrm{bcd}}$ & $871.8^{g}$ & $70.6^{f}$ & $51.5^{c}$ \\
\hline$P$-value & $* *$ & $* *$ & $* *$ & $* *$ & $* *$ & $* *$ & $* *$ & $* *$ & $* *$ & $* *$ & ** \\
\hline LSD & 2142.80 & 414.36 & 2196.60 & 34.34 & 111.64 & 121.40 & 4.92 & 8.96 & 88.65 & 6.31 & 3.75 \\
\hline
\end{tabular}

a-l - means with different superscripts within the some columne are significantly different at $P \leq 0.05$; ${ }^{* *}-P \leq 0.01$; LSD - least significant difference

\section{Discussion}

The present study was conducted to compare the nutritional composition of herbage of different Jerusalem artichoke genotypes and significant differences were observed in the nutrient contents among the examined genotypes. Crude protein contents varied between $6.59-16.56 \%$. It was reported that significant differences were observed in $\mathrm{CP}$ contents based on genotypes and harvest time (Seiler and Campbell, 2004; Ersahince and Kara, 2017). Khair Moh'D et al. (2000) indicated that CP content of feeds supplied to lactating sheep should be at least $7-9 \%$ to meet the survival ratio and at least $10-12 \%$ to meet the yield ratio. The majority of Jerusalem artichoke herbages used in the present study was within these ranges. Present $\mathrm{CP}$ values were similar to the values obtained by Ersahince and Kara (2017), Kaya and Caliskan (2010) and Karsli and Bingol (2009).

Kaya et al. (2009) indicated that the nutritional composition of the feed might vary with the stem, shoot and leaf ratios. Plant leaves are rich in protein and ash, and shoots are rich in cellulose (Kaplan et al., 2017). Temperature also significantly influences NDF content of the feed. Even at the same maturity, plants grown under higher temperatures have greater NDF contents than the plants grown under cold temperatures (Uslu et al., 2018).
According to ADF-based quality classification of Rohweder et al. (1978), present Jerusalem artichoke genotypes were classified as either the first or the second quality. Although present ADF and NDF greatly varied within the genotypes, current values were similar to the values obtained by Ersahince and Kara (2017), Karsli and Bingol, (2009) and Papi et al. (2019).

Plant oils contain essential nutrients, thus constitute a high-quality foodstuff and animal feed (Mehmood et al., 2008). Plant oils are not fixed and may vary with plant genetics, ecological factors, morphological traits and cultural practices (Baydar, 2000). Crude fat plays a significant role in the metabolic energy of the feeds (Menke and Steingass, 1988). In the present study, crude fat values were similar to the values presented by Kaya and Caliskan (2010) and Ersahince and Kara (2017).

Gas production largely depends on fermentable carbohydrate quantity and fermentation-induced gas production is a good indicator of carbohydrate quantity (Blümmel and Ørskov, 1993). The presence of tannin and saponin-like secondary metabolites also influences fermentation-induced gas production (Kondo et al., 2014; Kara, 2016). Methane production of Jerusalem artichoke genotypes and in vitro methane produced throughout the digestion of herbage were observed as expected (Kara et al., 2016). The methane-reduction potential of 
Jerusalem artichoke genotypes examined in the present study was classified as low anti-methanogenic according to the classification of López et al. (2010). Anti-methanogenic characteristics of Jerusalem artichoke samples play a significant role in animal feeding and have significant effects also on the environment. Fermentation-induced enteric methane contributes to global warming and results in feed energy losses, thus is not desired by environmentalists and animal growers. After carbon dioxide, methane is the second gas generating global warming. Despite low released quantity, methane holds solar heat 23 times greater than carbon dioxide (Cengiz and Kamalak, 2020). About $2-12 \%$ of digestible energy taken by ruminant animals are lost through methane production (Getachhew et al., 2005). About 2-3\% of condensed tannin prevent excessive and rapid protein degradation in the rumen (Barry, 1987). High-condensed tannins reduce protein digestibility (Kumar and Singh, 1984) and Frutos et al. (2002) indicated that condensed tannin content of less than $6.51 \%$ negatively influenced feed digestion.

Metabolizable energy, $\mathrm{OMD}$ and $\mathrm{NE}_{\mathrm{L}}$ values are calculated with the use of GP, EE (crude fat) and CP values (Menke and Steingass, 1988). Present genotypes had quite high protein, EE, NDF and ADF contents. Thus, differences were observed in $\mathrm{ME}, \mathrm{NE}_{\mathrm{L}}$ and OMD values of the genotypes.

Crude ash represents the mineral content of the feed (Gençtan, 1998). Minerals are not synthesized, thus should be taken externally (Doran, 2020). Mineral contents vary with the species, harvest time, soil and climate conditions and stress factors (Gralak et al., 2006). Terzić et al. (2012) investigated the mineral composition of above and below-ground parts of 141 different Jerusalem artichoke genotypes and reported significant differences in mineral contents among them. Present mineral contents were complying with the values reported by previous researchers.

Regarding macroelements of present Jerusalem artichoke genotypes, $\mathrm{Ca}$ contents varied between $1.6-4.5 \%$, P contents between $0.5-2.9 \%$, K contents between $2.0-3.3 \%$ and $\mathrm{Mg}$ contents varied between $0.3-0.7 \%$. Genotypes 33-1, 19-4, 50-4 and 58-1 were the richest ones in macroelements. In the present study, Jerusalem artichoke genotypes had similar $\mathrm{Ca}, \mathrm{P}, \mathrm{Mg}, \mathrm{K}, \mathrm{Na}$ and $\mathrm{S}$ contents as dry alfalfa hay commonly used in animal feeding and some had even greater values than alfalfa hay (NRC, 2001). Jerusalem artichoke genotypes generally had greater microelements ( $\mathrm{Fe}, \mathrm{Mn}, \mathrm{Zn}$ and $\mathrm{Cu}$ ) contents than leguminous and Gramineae species used in animal feeding (NRC, 2001).

\section{Conclusions}

Because of resistance to adverse environmental conditions, pests and diseases, high unit area yields and common use in human nutrition and animal feeding, Jerusalem artichoke is quite suitable for low-input agriculture. Jerusalem artichoke genotypes examined in the present study exhibited a large diversity in nutritional composition and can be considered to be a good source of fibre and minerals for ruminants. The Jerusalem artichoke genotypes used in the present study were rich in macro- and microelements, thus could be recommended as a rich source of roughage in ruminant diets prepared for dry and lactation periods. Besides in vitro gas production, other fermentation parameters including actual digestion levels and microbial protein productions should also be taken into consideration for a better selection of Jerusalem artichoke genotypes. Further research is recommended to test in vitro results through in vivo studies.

\section{Conflict of interest}

The authors declare that there is no conflict of interest.

\section{References}

Aksu Elmali D., Kaya I., 2012. The effects of different harvesting time on nutrient content of sainfoin (Onobrychis sativa L.) and vetch (Vicia sativa L). Lalahan Hay. Araşt. Enst. Derg. 52(2), 39-45

AOAC International, 2005. Official Methods of Analysis of AOAC International. 18 $8^{\text {th }}$ Edition. Gaithersburg, MD (USA)

Barry T.N., 1987. Secondary compounds of forages. In: J.B. Hacker, J.H. Ternouth (Editors). The Nutrition of Herbivores. Academic Press. Sydney (Australia)

Baydar H., 2000. The importance of cultivation in increasing the synthesis, quality and quality of oils in plants (in Turkish: Bitkilerde yağ sentezi, kalitesi ve kaliteyi artırmada islahın önemi). Ekin. Derg. 11, 50-57

Becker M., Nehring K. (Editors), 1969. Handbook of Feedstuffs (in German). Paul Parey Verlag. Hamburg and Berlin (Germany), pp. 159, 255, 340

Blümmel M., Ørskov E.R., 1993. Comparison of in vitro gas production and nylon bag degradability of roughages in predicting feed intake in cattle. Anim. Feed Sci. Technol. 40, 109-119, https:// doi.org/10.1016/0377-8401(93)90150-I

Cengiz T., Kamalak A., 2020. Determination of potential nutritive values and anti-methanogenic characteristics of Salix babylonica leaves grown in different sites. KSU J. Agric. Nat. 23, 1351-1358, https://doi.org/10.18016/ksutarimdoga.vi.679689

Doran T., 2020. Determination of herbage yield and quality characteristics of different sanguisorba minor scop genotypes. Master Thesis. Institute of Natural and Applied Sciences. Erciyes University. Talas/Kayseri (Turkey) 
Ersahince A.C., Kara K., 2017. Nutrient composition and in vitro digestion parameters of Jerusalem artichoke (Helianthus tuberosus L.) herbage at different maturity stages in horse and ruminant. J. Anim. Feed Sci. 26, 213-225, https://doi. org/10.22358/jafs/76477/2017

Frutos P., Hervás G., Ramos G., Giráldez F.J., Mantecón A.R., 2002. Condensed tannin content of several shrub species from a mountain area in northern Spain, and its relationship to various indicators of nutritive value. Anim. Feed Sci. Technol. 95, 215-226, https://doi.org/10.1016/S03778401(01)00323-6

Gençtan T., 1998. Agricultural Ecology (in Turkish: Tarımsal Ekoloji). Trakya University. Tekirdağ (Turkey)

Getachew G., Robinson P.H., DePeters E.J., Taylor S.J., Gisi D.D., Higginbotham G.E., Riordan T.J., 2005. Methane production from commercial dairy rations estimated using an in vitro gas technique. Anim. Feed Sci. Technol. 123-124, 391-402, https://doi.org/10.1016/j.anifeedsci.2005.04.056

Gralak M.A., Bates D.L., Von Keyserlingk M.A.G., Fisher L.J., 2006. Influence of species, cultivar and cut on the microelement content of grass forage. Slovak J. Anim. Sci. 39, 84-88

Gunnarsson I.B., Svensson S.-E., Johansson E., Karakashev D., Angelidaki I., 2014. Potential of Jerusalem artichoke (Helianthus tuberosus L.) as a biorefinery crop. Indust. Crop. Prod. 56, 231-240, https://doi.org/10.1016/j. indcrop.2014.03.010

Hanci F., Tuncer G., 2019. The investigation of the variation in tuber characteristics of Jerusalem artichoke collected from different provinces of Turkey. In: A. Güngör, K. Adilbekova (Editors). Proceeding Book of $5^{\text {th }}$ International Congress on Vocational \& Technical Sciences. Cairo (Egypt)

Kaplan M., Arslan M., Kale H., Kara K., Kökten K., 2017. GT biplot analysis for silage potential, nutritive value, gas and methane production of stay-green grain sorghum shoots. Int. J. Agric. Nat. Res. 44, 230-238, https://doi.org/10.7764/rcia.v44i3.1802

Kaplan M., Kamalak A., Kasra A.A., Güven I., 2014. Effect of maturity stages on potential nutritive value, methane production and condensed tannin content of Sanguisorba minor hay. Kafkas Üniv. Vet. Fak. Derg. 20, 445-449, https://doi.org/10.9775/ kvfd.2013.10383

Kara K., 2016. Effect of dietary fibre and condensed tannins concentration from various fibrous feedstuffs on in vitro gas production kinetics with rabbit faecal inoculum. J. Anim. Feed Sci. 25, 266-272, https://doi.org/10.22358/jafs/65563/2016

Kara K., Aktuğ E., Özkaya S., 2016. Ruminal digestibility, microbial count, volatile fatty acids and gas kinetics of alternative forage sources for arid and semi-arid areas as in vitro. Ital. J. Anim. Sci. 15, 673-680, https://doi.org/10.1080/182805 1X.2016.1249420

Kara K., Güçlü B.K., Baytok E., 2015. Comparison of nutrient composition and anti-methanogenic properties of different Rosaceae species. J. Anim. Feed Sci. 24, 308-314, https:// doi.org/10.22358/jafs/65613/2015

Kara K., Guclu B.K., Baytok E., Aktug E., Oguz F.K., Kamalak A., Atalay A., 2018. Investigation in terms of digestive values, silages quality and nutrient content of the using pomegranate pomace in the ensiling of apple pomace with high moisture contents. J. Appl. Anim. Res. 46, 1233-1241, https://doi.org/1 0.1080/09712119.2018.1490300

Karsli M.A., Bingol N.T., 2009. The determination of planting density on herbage yield and silage quality of Jerusalem artichoke (Helianthus tuberosus L.) green mass. Kafkas Üniv. Vet. Fak. Derg. 15, 581-586, https://doi.org/10.9775/kvfd.2009.069-A
Kaya İ., Ünal Y., Aksu Elmali D., 2009. Effects of different additives on the quality of grass silage and rumen degradability and rumen parameters of grass silage in rams. Kafkas Üniv. Vet. Fak. Derg. 15, 19-24

Kaya S., Caliskan M.E., 2010. Effects of molasses and ground wheat additions on the quality of groundnut, sweet potato, and Jerusalem artichoke tops silages. Afr. J. Agric. Res. 5, 829-833

Khair Moh'D., El-Shatnawi M.K., Mohawesh Y.M., 2000. Seasonal chemical composition of saltbush in semiarid grassland of Jordan. J. Range Manage. 53, 211-214, https://doi. org/10.2307/4003285

Kondo M., Hirano Y., Ikai N., Kita K., Jayanegara A., Yokota H., 2014. Assessment of anti-nutritive activity of tannins in tea by-products based on in vitro ruminal fermentation. Asian-Australas. J. Anim. Sci. 27, 1571-1576, https://doi. org/10.5713/ajas.2014.14204

Kumar R., Singh M., 1984. Tannins: Their adverse role in ruminant nutrition. J. Agric. Food Chem. 32, 447-453, https://doi. org/10.1021/jf00123a006

Lin B., Wang J.H., Lu Y., Liang Q., Liu J.X., 2013. In vitro rumen fermentation and methane production are influenced by active components of essential oils combined with fumarate. J. Anim. Physiol. Anim. Nutr. 97, 1-9, https://doi.org/10.1111/ j.1439-0396.2011.01236.x

Losavio N., Lamascese N., Vonella A.V., 1996. Water requirements and nitrogen fertilization in Jerusalem artichoke (Helianthus tuberosus L.) grown under Mediterranean conditions. Acta Hortic. 449, 205-210, https://doi.org/10.17660/ ActaHortic.1997.449.28

López S., Makkar H.P.S., Soliva C.R., 2010. Screening plants and plant products for methane inhibitors. In: P.E. Vercoe, H.P.S. Makkar, A.C. Schlink (Editors). In vitro Screening of Plant Resources for Extra-nutritional Attributes in Ruminants: Nuclear and Related Methodologies. Springer. Berlin/Heidelberg (Germany), pp. 191-231, https://doi. org/10.1007/978-90-481-3297-3_10

Ma X.Y., Zhang L.H., Shao H.B., Xu G., Zhang F., Ni F.T., Brestic M., 2011. Jerusalem artichoke (Helianthus tuberosus), a medicinal saltresistant plant has high adaptability and multiple-use values. J. Med. Plants Res. 5, 1272-1279

Makkar H.P.S., Blümmel M., Becker K., 1995. Formation of complexes between polyvinyl pyrrolidones or polyethylene glycols and tannins, and their implication in gas production and true digestibility in in vitro techniques. Br. J. Nutr. 73, 897-913, https://doi.org/10.1079/BJN19950095

Mehmood S., Orhan I., Ahsan Z., Aslan S., Gulfraz M., 2008. Fatty acid composition of seed oil of different Sorghum bicolor varieties. Food Chem. 109, 855-859, https://doi.org/10.1016/j. foodchem.2008.01.014

Menke K.H., Steingass H., 1988. Estimation of the energetic feed value obtained from chemical analysis and in vitro gas production using rumen fluid. Anim. Res. Develop. 28, 7-55

NRC (National Research Council), 2001. Nutrient Requirements of Dairy Cattle. $7^{\text {th }}$ Revised Edition. The National Academies Press. Washington, DC (USA), https://doi.org/10.17226/9825

Papi N., Kafilzadeh F., Fazaeli H., 2019. Use of Jerusalem artichoke aerial parts as forage in fat-tailed sheep diet. Small Rumin. Res. 174, 1-6, https://doi.org/10.1016/j.smallrumres.2019.03.001

Razmkhah M., Rezaei J., Fazaeli H., 2017. Use of Jerusalem artichoke tops silage to replace corn silage in sheep diet. Anim. Feed Sci. Technol. 228, 168-177, https://doi.org/10.1016/j. anifeedsci.2017.04.019 
Rohweder D.A., Barnes R.F., Jorgensen N., 1978. Proposed hay grading standards based on laboratory analyses for evaluating quality. J. Anim. Sci. 47, 747-759, https://doi.org/10.2527/ jas1978.473747x

Seiler G.J., 1988. Nitrogen and mineral content of selected wild and cultivated genotypes of Jerusalem artichoke. Argon. J. 80, 681-687, https://doi.org/10.2134/agronj1988.000219620080 $00040025 x$

Seiler G.J., Campbell L.G., 2004. Genetic variability for mineral element concentrations of wild Jerusalem artichoke forage. Crop Sci. 44, 289-292, https://doi.org/10.2135/cropsci2004.2890

Slimestad R., Seljaasen R., Meijer K., Skar S.L., 2010. Norwegiangrown Jerusalem artichoke (Helianthus tuberosus L.): morphology and content of sugars and fructo-oligosaccharides in stems and tubers. J. Sci. Food Agric. 90, 956-964, https:// doi.org/10.1002/jsfa.3903

Szpunar-Krok E., Bobrecka-Jamro D., Grochowska S., Buczek J., 2016. Yield of the aboveground parts and tubers of Jerusalem artichoke (Helianthus tuberosus L.) depending on plant density. Acta Sci. Pol. Agric. 15, 69-78
Terzić S., Atlagić J., Maksimović I., Zeremski T., Zorić M., Miklič V., Balalić I., 2012. Genetic variability for concentrations of essential elements in tubers and leaves of Jerusalem artichoke (Helianthus tuberosus L.). Sci. Hortic. 136, 135-144, https://doi.org/10.1016/j.scienta.2012.01.016

Uslu O.S., Kurt O., Kaya E., Kamalak A., 2018. Effect of species on chemical composition, metabolizable energy, organic matter digestibility and methane production of some legume plants grown in Turkey. J. Appl. Anim. Res. 46, 1158-1161, https:// doi.org/10.1080/09712119.2018.1480485

Van Soest P.J., Robertson J.B., Lewis B.A., 1991. Methods for dietary fiber, neutral detergent fiber, and nonstarch polysaccharides in relation to animal nutrition. J. Dairy Sci. 74, 3583-3597, https://doi.org/10.3168/jds.S00220302(91)78551-2

Yang J.Y., Seo J., Kim H.J., Seo S., Ha J.K., 2010. Nutrient synchrony: is it a suitable strategy to improve nitrogen utilization and animal performance? Asian-Australas. J. Anim. Sci. 23, 972-979, https://doi.org/10.5713/ajas.2010.r.04 